\title{
Keanekaragaman jenis dan perilaku menggigit vektor malaria (Anopheles spp.) di Desa Lifuleo, Kecamatan Kupang Barat, Kabupaten Kupang, Nusa Tenggara Timur
}

\author{
Species diversity and biting activity of malaria vectors (Anopheles spp.) \\ in Lifuleo Village, West Kupang District, East Nusa Tenggara \\ Ety Rahmawati ${ }^{1}$, Upik Kesumawati Hadi $^{2}{ }^{*}$, Susi Soviana ${ }^{2}$ \\ ${ }^{1}$ Politeknik Kesehatan Kementrian Kesehatan Kupang \\ Jalan Piet A. Tallo Liliba, Kupang 85111 \\ ${ }^{2}$ Bagian Parasitologi dan Entomologi Kesehatan, Fakultas Kedokteran Hewan IPB \\ Jalan Agatis Kampus Darmaga, Bogor 16880 \\ (diterima April 2013, disetujui September 2013)
}

\begin{abstract}
ABSTRAK
Malaria adalah penyakit yang dapat dicegah dan diobati, yang ditularkan melalui gigitan nyamuk dengan korban terbanyak adalah anak-anak dan wanita hamil. Indonesia adalah negara kedua yang terbanyak memiliki penderita malaria di Asia bagian selatan, setelah India. Penelitian ini dilakukan selama empat bulan, dan bertujuan memelajari keanekaragaman jenis dan perilaku menggigit vektor malaria (Anopheles spp.) di Desa Lifuleo, Kecamatan Kupang Barat, Kabupaten Kupang, Nusa Tenggara Timur. Penangkapan nyamuk dilakukan dengan tiga cara, yaitu (1) penggunaan teknik human landing collection, (2) penangkapan nyamuk yang hinggap di dalam rumah dan di kandang sapi, dan (3) pemakaian perangkap cahaya (light trap). Hasil penelitian mencatat terdapatnya enam spesies nyamuk, yaitu An. barbirostris, An. subpictus, An. annularis, An. vagus, An. umbrosus, dan An. indefinitus. Nyamuk An. barbirostris dan An. subpictus merupakan dua spesies dengan kepadatan tertinggi. Angka kepadatan per orang per jam (man hour density/MHD) di dalam rumah dan di luar rumah masing-masing untuk An. barbirostris adalah 5,45 dan 6,23, dan An. subpictus 1,35 dan 1,56. Puncak aktivitas menghisap darah di dalam dan di luar rumah masing-masing untuk An. barbirostris adalah pada pukul 22:00-04:00 dan 21:00-04:00, sedangkan An. subpictus pada pukul 20:00-21:00 dan 22:00-23:00. Berdasarkan rata-rata kepadatan setiap jam, nyamuk Anopheles spp. di Desa Lifuleo bersifat eksofagik dan eksofilik, yaitu lebih senang menghisap darah di luar rumah daripada di dalam rumah, dan lebih senang beristirahat di luar rumah.
\end{abstract}

Kata kunci: Anopheles barbirostris, Anopheles subpictus, eksofagik, eksofilik, Indonesia

\begin{abstract}
Malaria is a preventable and treatable mosquito-borne diseases, whose main victims are children and pregnant women. Indonesia is the second most affected region in South East Asia and has the the highest malaria burden after India. The research was aimed to study the species diversity and biting activity of malaria vectors (Anopheles spp.) in Lifuleo Village, West Kupang District, Kupang Regency, East Nusa Tenggara Province. The mosquitoes was collected by using (1) the human landing collection technique, (2) aspirators for collecting mosquitoes resting on the wall of houses and cow barn, and (3) light traps. The research was done for four months. The result showed that there were six

\footnotetext{
*Penulis korespondensi: Upik Kesumawati Hadi. Bagian Parasitologi dan Entomologi Kesehatan, Fakultas Kedokteran Hewan IPB, Jalan Agatis, Kampus IPB Darmaga, Bogor 16880 
species of Anopheles i.e., An. barbirostris, An. subpictus, An. annularis, An. vagus, An. umbrosus and An. indefinitus. An. barbirostris and An. subpictus were two species with the highest density. The value of man hour density (MHD) indoor and outdoor for An. barbirostris were 5.45 and 6.23 respectively, and for An. subpictus were 1.35 and 1.56, respectively. The blood sucking activity indoor and outdoor for An. barbirostris occured at 22:00 to 4:00 and 21:00 - 04 respectively, whereas for An. subpictus at 8:00 p.m. to 21:00 and 22:00 to 23:00, respectively. Based on the value of man hour density the mosquito Anopheles spp. in Lifuleo village were exophagic and exophilic.

Key words: Anopheles barbirostris, Anopheles subpictus, exophagic, exophilic, Indonesia

\section{PENDAHULUAN}

Malaria merupakan satu di antara penyakit yang dikategorikan berbahaya di dunia. Setiap tahunnya tercatat 300 sampai 500 juta kasus klinis malaria dan kematian 2,7 juta jiwa terutama pada anak-anak (WHO 2005). Indonesia merupakan negara terbanyak dengan penderita malaria setelah India di Asia bagian Selatan (WHO 2012), yang dapat menurunkan status kesehatan, produktivitas penduduk sehingga menjadi hambatan penting untuk pembangunan sosial dan ekonomi. Berdasarkan survei kesehatan rumah tangga (SKRT) tahun 1995, diperkirakan 15 juta penduduk terkena malaria, dan terjadi kematian pada dua persen dari total penderita malaria. Malaria di Provinsi Nusa Tenggara Timur (NTT) menempati ranking tertinggi nasional. Data survei kesehatan nasional tahun 2001 menunjukkan bahwa NTT memiliki angka kesakitan malaria 150 per 1.000 orang per tahun, diikuti oleh Papua 63,91 kasus per 1.000 penduduk per tahun (Depkes RI 2001). Data sistem surveilans terpadu (SST) tahun 2004 menempatkan penyakit malaria pada ranking pertama di NTT, 70\% penderita rawat jalan di Puskesmas dan rumah sakit umum (RSU) di Provinsi NTT adalah penderita malaria. Besarnya annual malariae incidence (AMI) di provinsi ini selama lima tahun berturut-turut sejak 2004 hingga 2008 adalah $168 \%$ o, $167 \%$ o, $145 \%$ o, $119 \%$ o, dan 83\%o (Dinkes Prov. NTT 2009).

Kabupaten Kupang mempunyai kasus malaria klinis atau AMI selama lima tahun berturut-turut adalah 214\%o (tahun 2004), 151\%o (tahun 2005), $183 \%$ o (tahun 2006), 88\%o (tahun 2007), dan $118 \%$ o (tahun 2008) (Dinkes Kab. Kupang 2009). Kabupaten ini memiliki 22 kecamatan, dan satu di antaranya, yaitu Kupang Barat, merupakan kecamatan dengan kasus malaria tertinggi dibandingkan dengan kecamatan lainya.
Kasus malaria klinis atau AMI selama empat tahun berturut-turut di Kecamatan Kupang Barat menunjukkan terjadi penurunan, yaitu $174 \%$ o tahun $2005,96 \%$ o tahun $2006,63 \%$ o tahun 2007 , dan $53 \%$ o tahun 2008. Desa Lifuleo merupakan wilayah tertinggi angka AMI dibandingkan dengan 11 desa lain yang berada di Kecamatan Kupang Barat dan mengalami peningkatan kasus pada tiga tahun terakhir, yaitu $96 \%$ o tahun 2006 , $165 \%$ o pada tahun 2007 , dan $226 \%$ o tahun 2008 (Puskesmas Batakte 2009).

Prevalensi malaria di Indonesia bagian timur lebih tinggi daripada di bagian barat, dan umumnya malaria disebabkan oleh Plasmodium falciparum (Elyazar et al. 2011) dan P. vivax (Elyazar et al. 2012). Vektor malaria di setiap daerah berbeda-beda dan bersifat lokal spesifik (Depkes RI 2007). Upaya pengendalian nyamuk Anopheles spp. yang merupakan vektor penyakit ini perlu dilakukan selain dengan tindakan pengobatan terhadap penderita. Hal ini merupakan usaha yang penting untuk menurunkan kasus malaria. Program penanggulangan malaria sudah dilaksanakan cukup lama di NTT dengan biaya yang dikeluarkan sangat besar. Namun, sampai saat ini hasilnya belum optimal, terlihat dari angka kesakitan yang masih tinggi, bahkan setiap tahun cenderung meningkat.

Pelaksanaan pengendalian vektor akan rasional, efektif dan efisien, apabila didukung oleh informasi mengenai vektornya, yaitu perilaku, distribusi dan musim penularan (Sigit 2006). Penguasaan bionomik vektor sangat diperlukan dalam perencanaan pengendalian vektor, dan akan memberi hasil maksimal, bila terdapat kesesuaian antara perilaku vektor selaku sasaran dan metode pengendalian yang diterapkan (Hadi 2010). Informasi mengenai hal tersebut sampai saat ini, terutama di Kabupaten Kupang dirasakan masih kurang. Oleh karena itu, studi perilaku nyamuk 
malaria di Kabupaten Kupang, NTT, sangat perlu dilakukan. Penelitian ini bertujuan untuk mengetahui keanekaragaman nyamuk Anopheles spp., dan fluktuasi populasi setiap spesies di Desa Lifuleo, Kecamatan Kupang Barat, Kabupaten Kupang. Manfaat penelitian ini diharapkan dapat memberikan sumbangan yang berarti di dalam upaya pengendalian vektor berdasarkan evidence.

\section{BAHAN DAN METODE}

\section{Lokasi penelitian}

Lokasi penelitian adalah Desa Lifuleo, Kecamatan Kupang Barat, Kabupaten Kupang, Provinsi Nusa Tenggara Timur. Penetapan lokasi penelitian dilakukan berdasarkan beberapa kriteria, yakni keanekaragaman jenis nyamuk Anopheles spp. lebih dari dua spesies, keberadaan tempat perindukan Anopheles spp. lebih dari dua tempat, kasus malaria tinggi, dan wilayah mudah dijangkau.

\section{Metode penelitian}

Penangkapan nyamuk dewasa dilakukan menggunakan tiga cara, yaitu menggunakan umpan orang (human landing collection), menangkap nyamuk yang istirahat (resting) di dinding rumah dan di kandang ternak, serta memakai perangkap cahaya (light trap) pada kandang ternak.

Penangkapan dengan umpan badan. Penelitian dilakukan seminggu sekali selama empat bulan dari Maret sampai Juni 2009. Tujuan kegiatan ini adalah untuk mengetahui keanekaragaman nyamuk Anopheles spp., dan fluktuasi populasi setiap spesies yang menyukai darah manusia. Sebanyak tiga buah rumah dipilih secara acak. Pada masing-masing rumah ditempatkan dua orang penangkap nyamuk, satu orang di dalam rumah dan satu orang lainnya di halaman dengan jarak 1,5 meter dari rumah. Penangkapan dimulai pada pukul 18:00 sampai 06:00 WITA dan ini dilakukan setiap jam selama 12 jam dengan lama penangkapan 40 menit per jam.

Penangkapan nyamuk yang hinggap di dinding rumah dan kandang sapi. Kegiatan bertujuan mengetahui keragaman nyamuk
Anopheles, dan banyaknya nyamuk yang hinggap di dinding dalam rumah dan di kandang sapi sebelum atau sesudah menggigit (perilaku istirahat). Penangkapan nyamuk yang hinggap di dinding rumah dilakukan oleh penangkap di dalam rumah, sedangkan di kandang sapi dilakukan oleh penangkap di luar rumah. Waktu penangkapan adalah dari pukul 18:00 sampai 06:00 WITA (selama 12 jam) dengan lama penangkapan 10 menit per jam.

Penangkapan dengan perangkap cahaya. Kegiatan dilakukan untuk mengetahui keragaman secara umum nyamuk Anopheles. Penangkapan nyamuk dengan perangkap cahaya dilakukan sepanjang malam antara pukul 18:00-06:00 WITA. Dua buah alat perangkap cahaya ditempatkan di dekat kandang sapi di lingkungan permukiman penduduk.

Identifikasi nyamuk. Nyamuk yang berhasil ditangkap pada semua metode penangkapan di lokasi penelitian kemudian diidentifikasi. Identifikasi dilakukan di bawah mikroskop stereo XTB-IB 030234 sampai tingkat spesies menggunakan kunci determinasi O'Connor \& Soepanto (1999).

Pengukuran curah hujan, suhu dan kelembapan udara. Data curah hujan diperoleh dari Badan Meteorologi dan Geofisika Kabupaten Kupang, sedangkan suhu dan kelembapan diperoleh dari hasil pengukuran setiap jam menggunakan higrotermometer, mulai pukul 18:00 sampai 06:00 WITA saat penangkapan nyamuk di lokasi penelitian,

\section{Analisis data}

Nyamuk yang tertangkap dengan menggunakan umpan orang dan yang hinggap di dinding serta light trap dianalisis secara deskriptif dan disajikan dalam bentuk tabel dan grafik. Untuk mengetahui hubungan iklim (curah hujan, suhu, dan kelembaban) dengan kepadatan Anopheles spp., dilakukan analisis dengan menggunakan uji korelasi Pearson. Apabila terdapat hubungan yang signifikan, selanjutnya dilihat pengaruhnya dengan uji Regresi Linier menggunakan perangkat lunak SPSS 15.00 for Windows dengan tingkat kepercayaan $95 \%(\alpha=5 \%)$. 


\section{HASIL}

\section{Keanekaragaman jenis nyamuk Anopheles spp.}

Jenis nyamuk Anopheles yang tertangkap dengan berbagai cara di Desa Lifuleo, Kecamatan Kupang Barat terdiri atas enam spesies, yaitu An. barbirostris (Gambar 1A), An. subpictus (Gambar 1B), An. annularis (Gambar 1C), An. vagus (Gambar 1D), An. umbrosus (Gambar 1E), dan An. indefinitus (Gambar 1F). Spesies nyamuk Anopheles tidak hanya ditemukan pada satu metode penangkapan, tetapi juga ditemukan sedang menghisap darah orang di dalam rumah dan luar rumah, hinggap di dinding di dalam rumah dan kandang sapi. Nyamuk Anopheles yang tertangkap menggunakan perangkap cahaya (light traps) terdiri atas lima spesies, yaitu $A n$. barbirostris, An. subpictus, An. annularis, An. vagus, dan An. umbrosus (Tabel 1).

Keanekaragaman jenis nyamuk Anopheles spp. berdasarkan tempat menghisap darah dan istirahat (resting) lebih rinci disajikan Tabel 2. Jenis An. barbirostris terlihat banyak tersebar di luar rumah dan kandang sapi. Persentase nyamuk yang menghisap darah di luar rumah adalah $32,22 \%$ dan sekitar kandang sapi adalah $24,16 \%$. Lebih dari separuh populasi berhasil dikumpulkan dari luar rumah. Meskipun demikian jenis ini ditemukan juga aktif menghisap darah di dalam rumah $(28,25 \%)$ dan hinggap di dinding $(14,84 \%)$, sedangkan yang tertangkap dengan light trap hanya mencapai $0,53 \%$.

Sebagian besar populasi An. subpictus ditemukan dari luar rumah sebesar 31,91\%, di sekitar kandang dan aktif menghisap darah orang
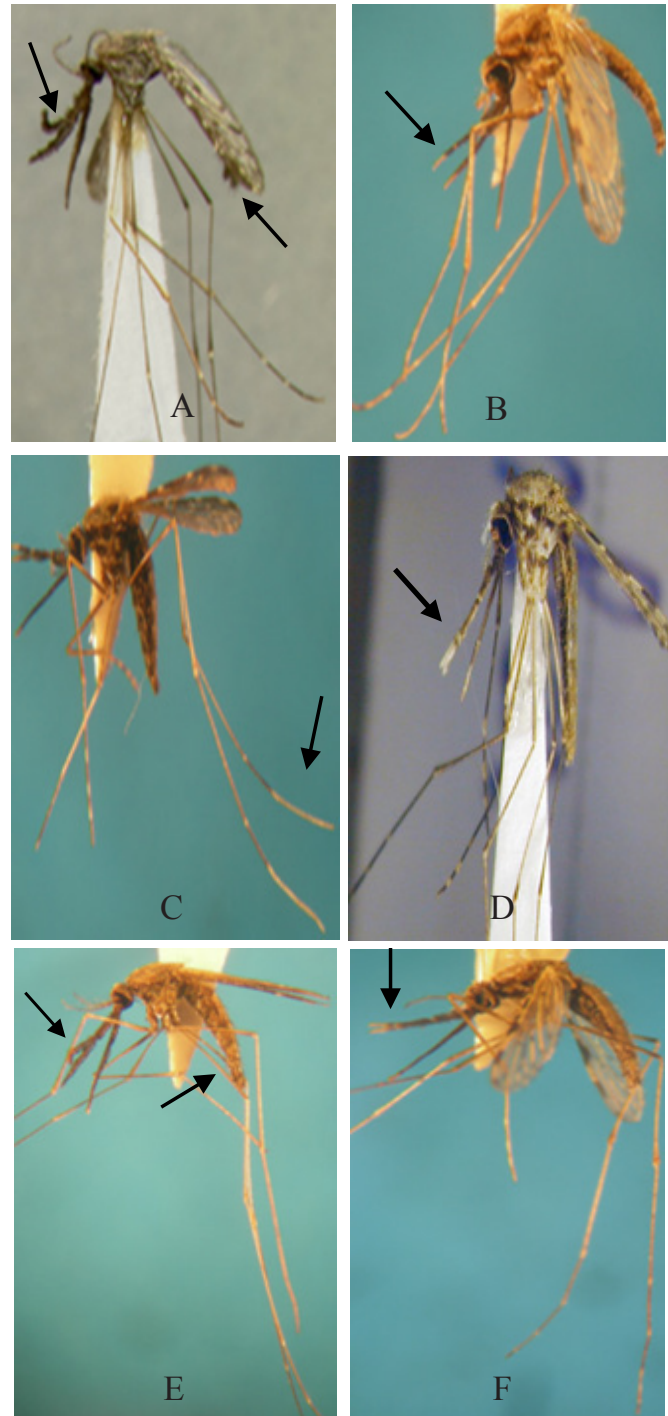

Gambar 1. Nyamuk Anopheles spp. di Desa Lifuleo Kecamatan Kupang Barat Kabupaten Kupang. A: An. barbirostris; B: An. subpictus; C:An. annularis; D:An.vagus; E: An. umbrosus; F: An. indefinitus. Gambar panah merupakan ciri khas morfologi dari setiap jenis nyamuk A-F.

Tabel 1. Jumlah dan persentase nyamuk Anopheles spp. yang tertangkap dengan berbagai metode penangkapan di Desa Lifuleo, Maret-Juni 2009

\begin{tabular}{|c|c|c|c|c|c|c|c|c|c|c|}
\hline \multirow{2}{*}{$\begin{array}{l}\text { Spesies } \\
\text { Anopheles }\end{array}$} & \multicolumn{2}{|c|}{ UOD } & \multicolumn{2}{|c|}{ UOL } & \multicolumn{2}{|c|}{ Dinding } & \multicolumn{2}{|c|}{ Kandang } & \multicolumn{2}{|c|}{ Light trap } \\
\hline & $\mathrm{Jml}$ & $\%$ & $\mathrm{Jml}$ & $\%$ & $\mathrm{Jml}$ & $\%$ & $\mathrm{Jml}$ & $\%$ & $\mathrm{Jml}$ & $\%$ \\
\hline An.barbirostris & 2.097 & 73,89 & 2.392 & 71,51 & 1.102 & 72,12 & 1.794 & 58,04 & 39 & 60,94 \\
\hline An.subpictus & 519 & 18,29 & 598 & 17,88 & 293 & 19,18 & 665 & 22,14 & 9 & 14,06 \\
\hline An.annularis & 19 & 0,67 & 20 & 0,60 & 3 & 0,20 & 34 & 1,04 & 1 & 1,56 \\
\hline An.vagus & 113 & 3,98 & 202 & 6,04 & 94 & 6,15 & 379 & 12,62 & 12 & 18,75 \\
\hline An.umbrosus & 82 & 2,89 & 113 & 3,38 & 31 & 2,03 & 166 & 5,53 & 3 & 4,69 \\
\hline An.indefinitus & 8 & 0,28 & 20 & 0,60 & 5 & 0,33 & 55 & 1,78 & 0 & 0 \\
\hline Total & 2.838 & 100 & 3.345 & 100 & 1.528 & 100 & 3.093 & 100 & 64 & 100 \\
\hline
\end{tabular}

Jml: jumlah; UOD: umpan badan dalam rumah; UOL: umpan badan luar rumah. 
luar rumah $(28,69 \%)$, menghisap darah di dalam rumah $24,9 \%$, dan tertangkap perangkap cahaya 0,43\%. Empat spesies Anopheles lain, yaitu An. annularis, An. vagus, An. umbrosus dan An. indefinius separuh populasinya ditemukan di luar rumah dan sebagian besar ditemukan di kandang sapi (Tabel 2). Hasil ini memperlihatkan nyamuk Anopheles lebih banyak menghisap darah orang di luar rumah daripada di dalam rumah.

\section{Fluktuasi aktivitas menghisap darah Anopheles} spp.

Aktivitas menghisap darah nyamuk Anopheles di dalam rumah dan di luar rumah dapat dilihat dari Gambar 2 dan Gambar 3. An. barbirostris merupakan jenis yang paling dominan dibandingkan dengan lima spesies lainya pada penangkapan umpan badan di dalam rumah dan di luar rumah. Jenis nyamuk ini merupakan vektor malaria di NTT yang ditemukan menghisap darah sepanjang malam, antara pukul 18:00-06:00 baik di dalam maupun di luar rumah. Puncak kepadatan nyamuk ini menghisap darah orang di dalam rumah terjadi pada pukul 22:00-04:00, sedangkan di luar rumah pada pukul 21:00-04:00. An. subpictus merupakan jenis yang terbanyak kedua setelah An. barbirostris dan juga vektor malaria, aktif menghisap darah antara pukul 18:00-06:00, dan puncak gigitan terjadi pada pukul 20:00-
01:00 di dalam rumah, dan pukul 22:00-23:00 di luar rumah. An. vagus menduduki urutan ketiga dengan puncak gigitan terjadi pukul 22:00-23:00 di dalam rumah dan di luar rumah. An. umbrosus merupakan nyamuk yang dominan setelah $A n$. vagus dengan puncak kepadatan menggigit di dalam rumah pukul 20:00-21:00 dan 24:00-03:00, dan di luar rumah pukul 22:00-23:00.

An. annularis dan An. indefinitus merupakan dua spesies yang tidak dominan di Desa Lifuleo. An. annularis tertangkap hanya pada bulan Maret dan April, dan puncak kepadatan menggigit orang di dalam rumah pukul antara 23:00-24.00 dan 02:00-03:00, di luar rumah antara 19:0020:00 dan 02:00-03:00. Nyamuk An. indefinitus memiliki puncak kepadatan menggigit orang di dalam rumah antara pukul 20:00-21:00, dan di luar rumah antara pukul 24:00-03:00.

\section{Hubungan kepadatan nyamuk dengan suhu, kelembaban, dan curah hujan}

Perbedaan kepadatan nyamuk pada setiap jam penangkapan dipengaruhi oleh tinggi rendahnya suhu dan kelembapan yang dapat terlihat pada Gambar 4 dan Gambar 5. Selama penelitian berlangsung, suhu lingkungan pada malam hari adalah antara $24{ }^{\circ} \mathrm{C}$ dan $29{ }^{\circ} \mathrm{C}$ dan kelembapan antara $71 \%$ dan $86 \%$. Suhu tertinggi terjadi pada jam 18:00-20:00 dan terendah pada jam 02:00-

Tabel 2. Komposisi keanekaragaman nyamuk Anopheles spp. yang tertangkap dengan berbagai metode penangkapan di Desa Lifuleo, Maret-Juni 2009

\begin{tabular}{|c|c|c|c|c|c|c|}
\hline \multirow{2}{*}{ Spesies Anopheles } & \multirow{2}{*}{ Jumlah } & \multicolumn{2}{|c|}{ Umpan badan (BLC) } & \multicolumn{2}{|c|}{ Hinggap } & \multirow{2}{*}{ Light trap } \\
\hline & & Dalam & Luar & Dinding & Kandang & \\
\hline \multirow[t]{2}{*}{ An. barbirostris } & 7.424 & 2.097 & 2.392 & 1.102 & 1.794 & 39 \\
\hline & & $(28,25 \%)$ & $(32,22 \%)$ & $(14,84 \%)$ & $(24,16 \%)$ & $(0,53 \%)$ \\
\hline \multirow[t]{2}{*}{ An. subpictus } & 2.084 & 519 & 598 & 293 & 665 & 9 \\
\hline & & $(24,9 \%)$ & $(28,69 \%)$ & $(14,06 \%)$ & $(31,91 \%)$ & $(0,43 \%)$ \\
\hline \multirow[t]{2}{*}{ An. annularis } & 77 & 19 & 20 & 3 & 34 & 1 \\
\hline & & $(24,68 \%)$ & $(25,97 \%)$ & $(3,9 \%)$ & $(44,16 \%)$ & $(1,3 \%)$ \\
\hline \multirow[t]{2}{*}{ An. vagus } & 800 & 113 & 202 & 94 & 379 & 12 \\
\hline & & $(14,13 \%)$ & $(25,25 \%)$ & $(11,75 \%)$ & $(47,38 \%)$ & $(1,5 \%)$ \\
\hline \multirow[t]{2}{*}{ An. umbrosus } & 395 & 82 & 113 & 31 & 166 & 3 \\
\hline & & $(20,76 \%)$ & $(28,61 \%)$ & $(7,85 \%)$ & $(42,03 \%)$ & $(0,76 \%)$ \\
\hline \multirow[t]{2}{*}{ An. indefinitus } & 88 & 8 & 20 & 5 & 55 & 0 \\
\hline & & $(9,09 \%)$ & $(22,73 \%)$ & $(5,68 \%)$ & $(62,5 \%)$ & 0 \\
\hline \multirow[t]{2}{*}{ Total } & 10.868 & 2.838 & 3.345 & 1.528 & 3.093 & 64 \\
\hline & $(100 \%)$ & $(26,11 \%)$ & $(30,78 \%)$ & $(14,06 \%)$ & $(28,46 \%)$ & $(0,59 \%)$ \\
\hline
\end{tabular}




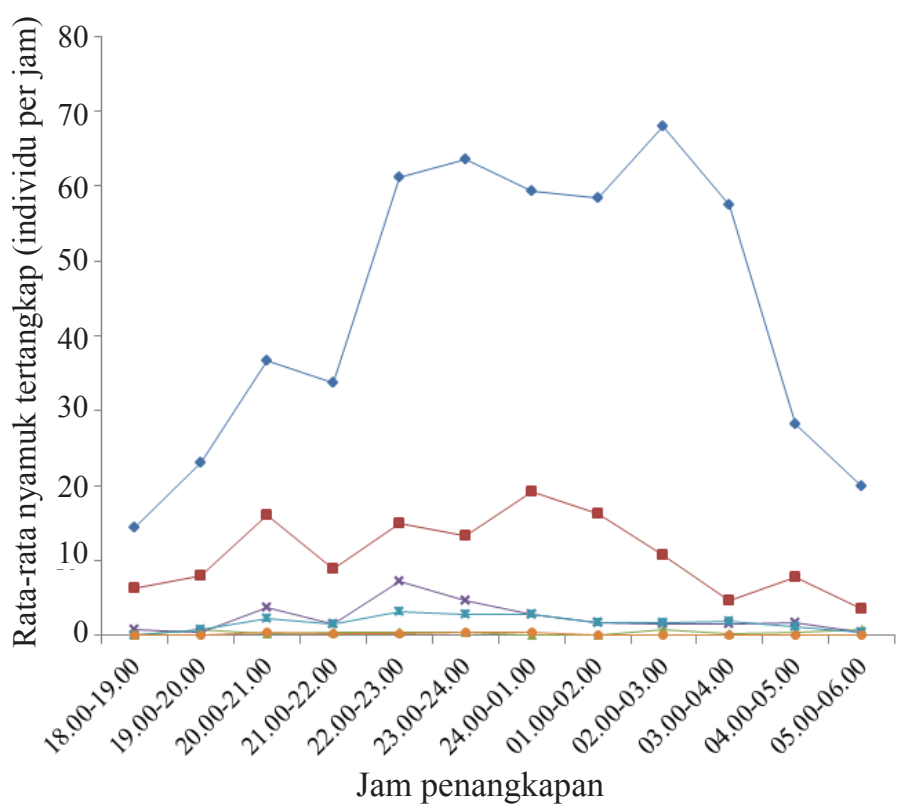

Gambar 2. Rata-rata nyamuk Anopheles spp. yang tertangkap dengan umpan orang dalam rumah pada jam 18:00-06:00 di Desa Lifuleo, Kecamatan Kupang Barat, Maret-Juni 2009. ㄷ: Anopheles barbirostris; $-:$ :An. subpictus; $\multimap$ : An. annularis; $\multimap$ :An. vagus; $\multimap$ : An. umbrosus; $\multimap$ : An. indefinitus.

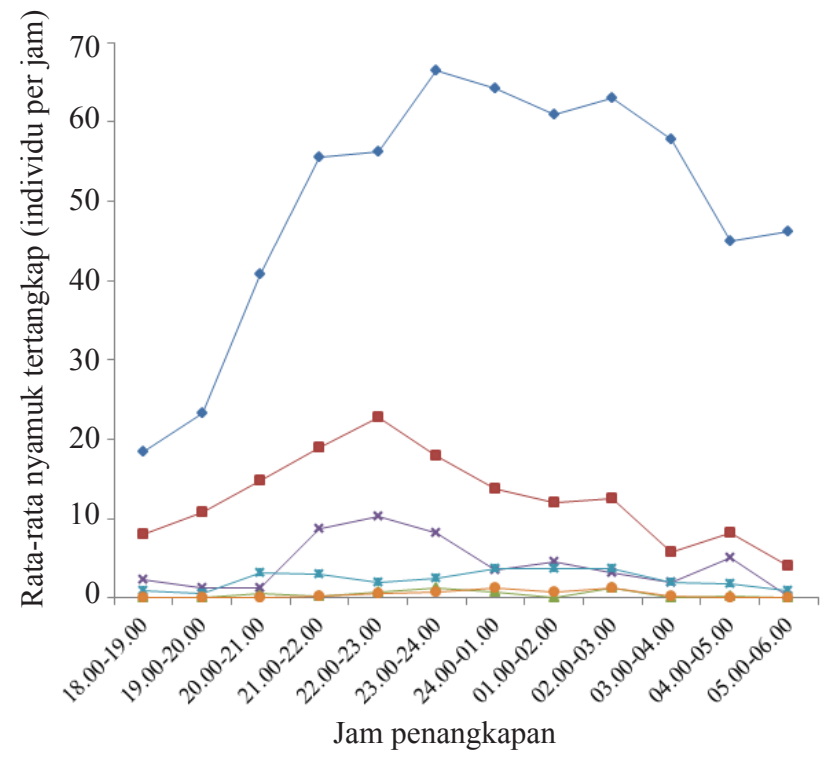

Gambar 3. Rata-rata nyamuk Anopheles spp. yang tertangkap dengan umpan orang luar rumah pada jam 18:00-06:00 di Desa Lifuleo, Kecamatan Kupang Barat, Maret-Juni 2009. -: Anopheles

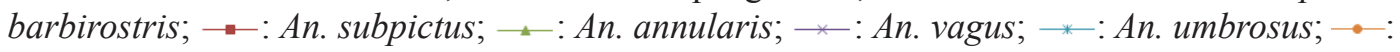
An. indefinitus.

04:00. Pada suhu diatas $26^{\circ} \mathrm{C}$ rata-rata kepadatan Anopheles mengalami penurunan dan puncak kepadatannya dapat terjadi pada suhu $24{ }^{\circ} \mathrm{C}$ sampai $26{ }^{\circ} \mathrm{C}$. Kelembapan terendah terjadi pada jam 18:00-19:00 dan tertinggi pada jam 02:0004:00. Namun demikian tidak ada hubungan yang signifikan antara kepadatan Anopheles dan suhu $(\mathrm{Fdb}=3,005,11 ; \mathrm{P}=0,057>0,05$,$) dan$ kelembaban udara $(\mathrm{Fdb}=1,164,11 ; \mathrm{P}=0,153>$ 0,05, ).

Nyamuk Anopheles yang tertangkap di Desa Lifuleo, Kecamatan Kupang Barat, mulai awal Maret hingga akhir Juni menunjukkan fluktuasi yang bervariasi pada masing-masing spesies selama 16 minggu penangkapan. Kondisi curah hujan di Desa Lifuleo berbanding lurus dengan 


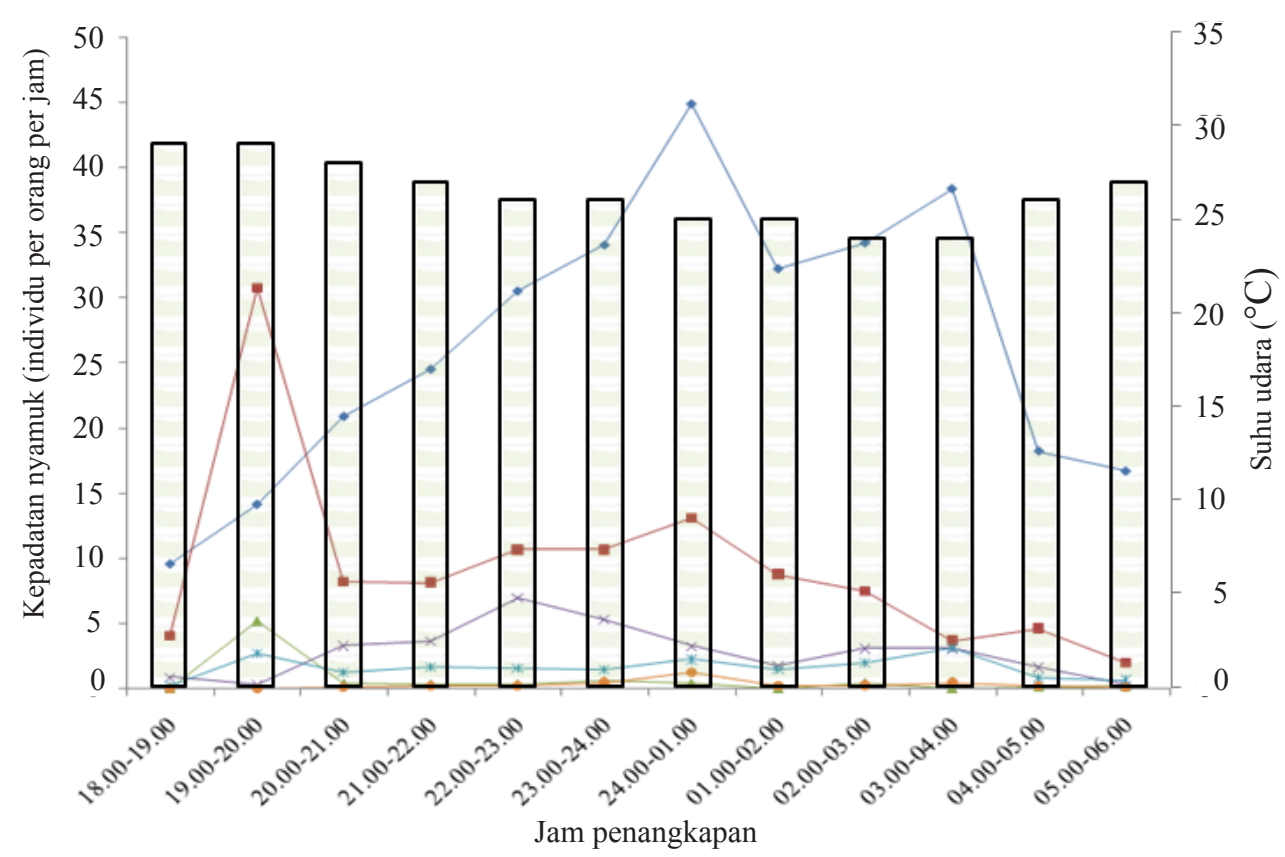

Gambar 4. Hubungan kepadatan nyamuk Anopheles spp. dan suhu jam 18.00-06.00 di Desa Lifuleo Kecamatan Kupang Barat, Maret-Juni 2009. -: Anopheles barbirostris; $-\rightarrow$ : An. subpictus; $\rightarrow:$ An. annularis; $\multimap$ : An. vagus; $\rightarrow$ : An. umbrosus; $\rightarrow$ : An. indefinitus; $\square$ : suhu.

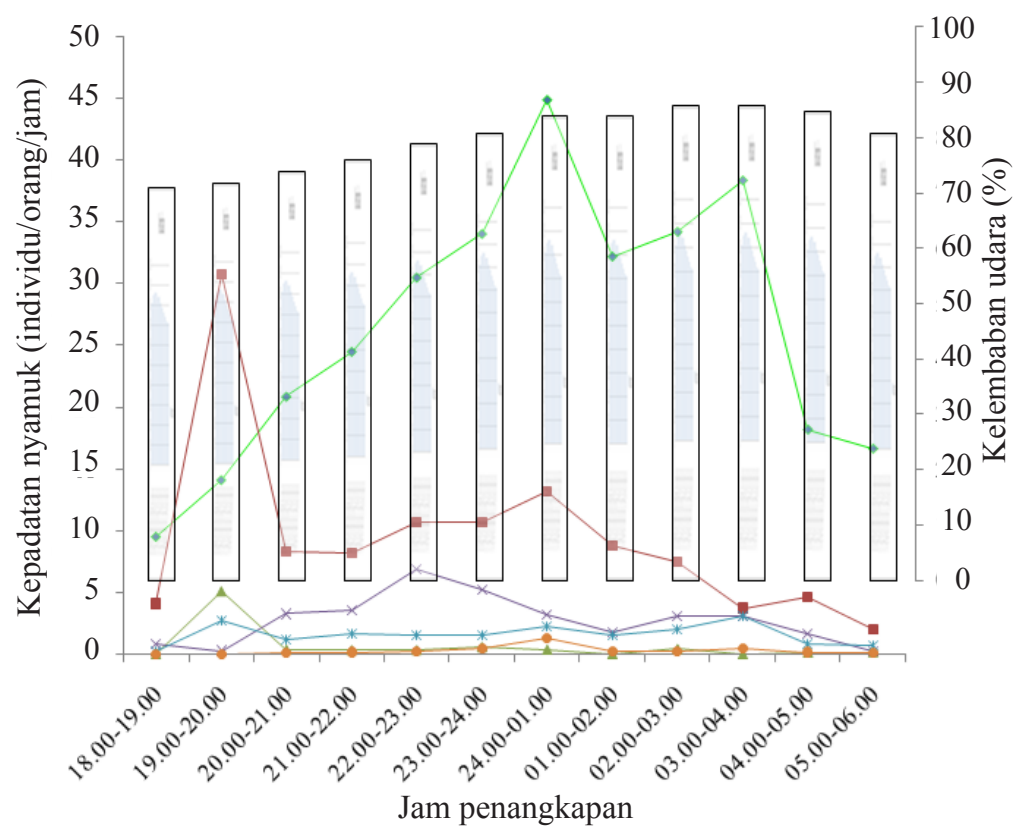

Gambar 5. Hubungan kepadatan nyamuk Anopheles spp. dan kelembaban jam 18:00-06:00 di Desa Lifuleo, Kecamatan Kupang Barat, Maret-Juni 2009. -: Anopheles barbirostris; -- : An. subpictus; $\leadsto:$ An. annularis; $\rightarrow:$ An. vagus $; \multimap:$ An. umbrosus $; \cdots:$ An. indefinitus; $\square$ : kelembaban.

kepadatan Anopheles, yaitu jika curah hujan tinggi maka kepadatan Anopheles juga meningkat (Gambar 6).

Secara umum enam spesies yang tertangkap menunjukkan kepadatan yang tinggi pada bulan Maret dan selanjutnya terus menurun pada bulan April-Juni. Hal ini mungkin dipengaruhi oleh curah hujan dan ketersediaan tempat perindukan di lokasi tersebut. Curah hujan di Kabupaten Kupang bulan Maret-Juni 2009 berkisar antara $0-50,81 \mathrm{~mm} / \mathrm{bulan}$, dan pada bulan Maret sangat tinggi $(50,81 \mathrm{~mm} /$ bulan $)$ dan selanjutnya menurun hingga bulan Juni tidak terdapat hujan $(0 \mathrm{~mm} /$ bulan). Hal ini didukung oleh hasil uji statistik, 96,3\% fluktuasi kepadatan nyamuk Anopheles spp. yang tertangkap dipengaruhi oleh keadaan 


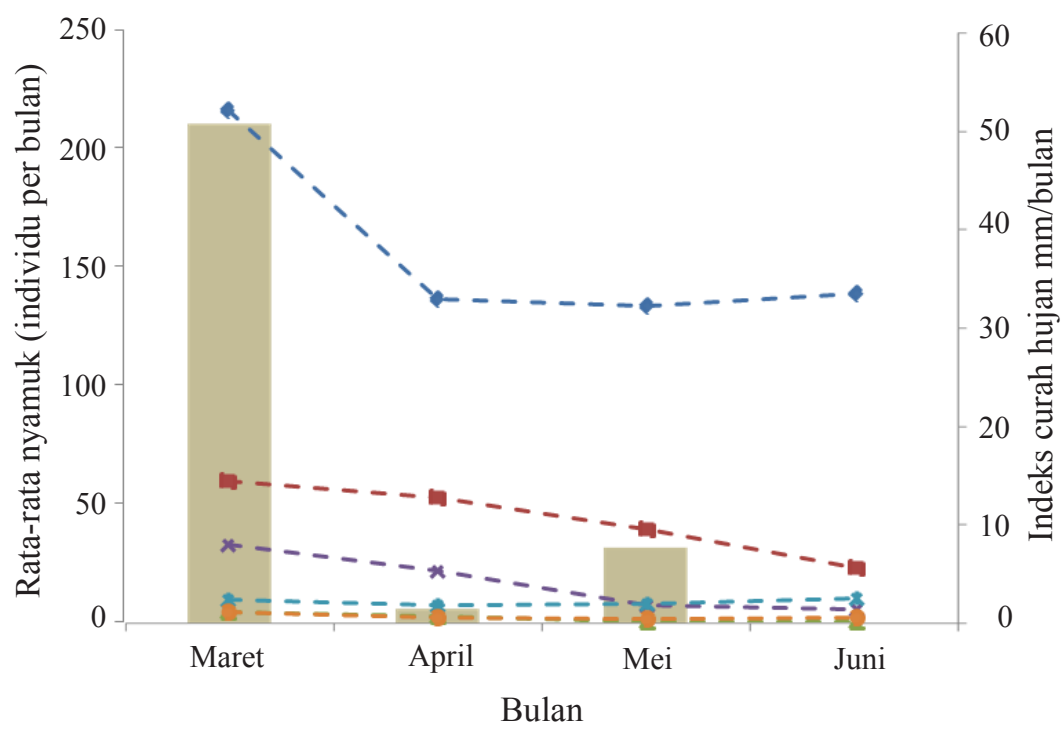

Gambar 6. Hubungan kepadatan nyamuk Anopheles spp. dan curah hujan di Desa Lifuleo, Kecamatan Kupang Barat, Maret-Juni 2009. - -: Anopheles barbirostris; - —-: An. annularis; - - - An. subpictus; - - -:An. vagus; ": curah hujan.

curah hujan $(\mathrm{F}=52,714, \mathrm{db}=3 ; \mathrm{P}=0,018<0,05)$, sedangkan sisanya bisa dipengaruhi oleh faktor lain, seperti suhu, kelembaban, dan kecepatan angin.

\section{PEMBAHASAN}

Selama penelitian dari enam spesies yang ditemukan di Desa Lifuleo, Kecamatan Kupang Barat terdapat lima spesies yang secara teratur ditemukan pada setiap penangkapan, yaitu An. barbirostris, An. subpictus, An. vagus, An. umbrosus, dan An. indefinitus, sedangkan spesies An. annularis hanya ditemukan pada bulan Maret dan April saja. Jumlah nyamuk Anopheles yang tertangkap pada setiap penangkapan sangat berfluktuasi.

Berdasarkan hasil metode penangkapan, terlihat bahwa Anopheles paling banyak tertangkap dengan cara umpan badan luar rumah. Hal ini menunjukkan bahwa nyamuk Anopheles yang ada di Desa Lifuleo lebih banyak menghisap darah manusia yang berada di luar rumah (eksofagik).

Jika data tersebut dikaitkan dengan beberapa penemuan nyamuk di lokasi penelitian di daerah lain maka terdapat spesies Anopheles yang sama. Hal ini mungkin disebabkan oleh kondisi lingkungan dan habitat yang tidak jauh berbeda. Jastal (2005) melaporkan bahwa di Desa Tongoa, Donggala, Sulawesi Tengah terdapat dua spesies
Anopheles, yaitu An. barbirostris (45,70\%), An. vagus (42\%). Di Kabupaten Sukabumi terdapat lima spesies nyamuk An. barbirostris, An. annularis, An. vagus, dan An. indefinitus. An. vagus merupakan spesies yang paling dominan dengan persentase 96,61\% (Munif et al. 2008).

Nyamuk Anopheles yang tertangkap di Desa Lifuleo Kecamatan Kupang Barat sejak awal Maret hingga akhir Juni menunjukkan fluktuasi bervariasi pada masing-masing spesies selama 16 minggu penangkapan. Namun demikian, secara umum enam spesies yang tertangkap menunjukkan kepadatan yang tinggi pada bulan Maret dan selanjutnya terus menurun selama bulan April-Juni. Hal ini mungkin dipengaruhi oleh curah hujan dan ketersediaan tempat perindukan di lokasi tersebut. Curah hujan di Kabupaten Kupang bulan Maret-Juni 2009 berkisar antara 0-50,81 mm/bulan, dan pada bulan Maret sangat tinggi $(50,81 \mathrm{~mm} /$ bulan$)$ dan selanjutnya menurun hingga bulan Juni tidak terdapat hujan $(0 \mathrm{~mm} /$ bulan) (BMG Kab. Kupang 2009).

Kondisi curah hujan di Desa Lifuleo berbanding lurus dengan kepadatan Anopheles, yaitu curah hujan tinggi kepadatan Anopheles juga meningkat. Hasil ini berbeda dengan hasil penelitian di Desa Hargotirto, Kulonprogo (Effendi 2002) yang menunjukkan indeks curah hujan dan nyamuk Anopheles berbanding terbalik. Saat curah hujan tinggi kepadatan nyamuk Anopheles menurun, sedangkan pada kondisi curah hujan yang rendah 
kepadatan cenderung tinggi. Perbedaan ini disebabkan oleh perbedaan kondisi daerah. Desa Lifuleo merupakan daerah pesisir pantai dengan indeks curah hujan rendah, apabila curah hujan berkurang atau tidak ada maka habitat larva yang bersifat semi permanen langsung mengering, dan berakibat pada kurangnya kepadatan atau bahkan hilangnya sebagian spesies Anopheles. Sementara itu, Desa Hargotirto merupakan daerah pegunungan dengan indeks curah hujan lebih tinggi sehingga memiliki jenis habitat yang saat hujan tinggi dapat menurunkan populasi nyamuk bahkan menghilangkan habitat perkembangbiakan.

Kepadatan nyamuk Anopheles spp. yang tertangkap di Desa Lifuleo, Kabupaten Kupang, dipengaruhi oleh keadaan curah hujan. Hasil tersebut senada dengan penelitian Hakim \& Ipa (2007) di Kabupaten Sukabumi bahwa curah hujan mempunyai hubungan erat dengan kepadatan nyamuk Anopheles. Curah hujan juga berhubungan dengan fluktuasi kesakitan malaria. Kepadatan vektor yang tinggi pada musim hujan dapat meningkatkan angka kesakitan malaria pada musim hujan juga menjadi tinggi.

Nyamuk Anopheles mempunyai aktivitas menghisap darah pada malam hari dan berfluktuasi pada jam-jam tertentu. Berdasarkan waktu menghisap darah beberapa spesies nyamuk Anopheles mempunyai aktivitas pada awal matahari terbenam sampai matahari terbit. Umumnya spesies nyamuk Anopheles mempunyai dua puncak gigitan pada malam hari yang berbeda di antara satu spesies dan spesies lainnya. Puncak aktivitas pertama ditemukan sebelum tengah malam dan puncak gigitan kedua menjelang pagi hari. Keadaan ini dapat berubah karena adanya pengaruh suhu, dan kelembapan udara yang dapat menyebabkan bertambah atau berkurangnya kehadiran nyamuk Anopheles di suatu tempat. Penangkapan nyamuk dengan umpan orang memperoleh enam spesies Anopheles. Dua spesies di antaranya (An barbirostris dan An. subpictus) memperlihatkan fluktuasi gigitan tertinggi yang berbeda.

An. barbirostris yang merupakan jenis yang paling dominan dibandingkan dengan lima spesies lainya, dan merupakan vektor malaria di NTT yang ditemukan menghisap darah sepanjang malam, dari pukul 18:00-06:00 baik di dalam maupun di luar rumah. Puncak menghisap darah An. barbirostris terjadi pada pukul 22:00-04:00 di dalam rumah, sedangkan di luar rumah pada pukul 21.0004:00. Hasil ini sama dengan An. barbirostris di Kabupaten Parigi Moutong, Sulawesi Tengah (Garjito et al. 2004). Hal ini berarti An.barbirostris menghisap darah terbanyak pada sekitar tengah malam, pada waktu sebagian besar penduduk sedang beristirahat (tidur). Sebaliknya, jenis ini mempunyai perilaku yang berbeda dengan yang ditemukan di Provinsi Sa Kaeo, Thailand yang mengigit antara pukul 21:00-24:00, saat sebagian penduduk masih melakukan aktivitas baik di dalam maupun di luar rumah (Limrat et al. 2001). Demikian juga di Sulawesi Tenggara, puncak menghisap darah nyamuk ini terjadi menjelang malam, yaitu pukul 19:00-21:00 (Depkes RI 2007). Artinya, jenis nyamuk ini memiliki perilaku menghisap darah yang berbeda dari satu tempat dengan tempat lain.

Nyamuk An. subpictus merupakan jenis yang paling dominan kedua setelah An. barbirostris dan juga sebagai vektor. Perilaku menggigit nyamuk ini tidak jauh berbeda dengan yang ditemukan di Kabupaten Parigi Moutong, Sulawesi Tengah (Garjito et al. 2004), dengan puncak menghisap darah pukul 21:00-03:00 (tengah malam). Namun demikian, jenis ini berbeda perilaku dengan yang ditemukan di Tanjung Bunga, Flores Timur, dimana puncak menghisap darah terjadi pada pukul 20:00-22:00 (Barodji et al. 2000).

Nyamuk An. barbirostris dan An. subpictus menjadi vektor malaria di NTT sehingga keberadaan kedua spesies ini dapat mempengaruhi jumlah kasus malaria di provinsi tersebut. Data dari Puskesmas Batakte menunjukkan bahwa kasus malaria di Desa Lifuleo pada tahun 2008 tertinggi pada bulan Maret, yaitu $88 \%$ dan selanjutnya menurun. Demikian juga pada tahun 2009, dari bulan Maret sampai Juni cenderung menurun $(35,9 \%, 32,8 \%, 12,7 \%$, dan 5,29\%). Hal ini seiring dengan kapadatan nyamuk Anopheles yang tertangkap semakin berkurang $(3.295,2.668$, 1.897, dan 1.243 individu). Hasil uji statistik mendukung, yaitu sebesar $94,8 \%$ fluktuasi kasus malaria di Desa Lifuleo dipengaruhi oleh fluktuasi kepadatan nyamuk An.barbirostris dan An. subpictus pada tingkat kepercayaan 95\% ( $p<$ $0,05)$. 
Kepadatan nyamuk pada setiap jam penangkapan dipengaruhi oleh tinggi rendahnya suhu dan kelembaban. Pada suhu diatas $26{ }^{\circ} \mathrm{C}$, rata-rata kepadatan Anopheles mengalami penurunan dan puncak kepadatannya pada suhu $24{ }^{\circ} \mathrm{C}$ sampai $26{ }^{\circ} \mathrm{C}$. Pada kelembaban kurang dari $81 \%$ dan lebih dari $86 \%$ rata-rata kepadatan Anopheles mengalami penurunan, sedangkan puncak kepadatan terjadi pada kelembaban $74 \%$ $-84 \%$. Hal tersebut didukung oleh Russel et al. (1963) yang menyatakan bahwa suhu udara 25 ${ }^{\circ} \mathrm{C}-27{ }^{\circ} \mathrm{C}$ dan kelembaban antara $80-90 \%$ sesuai untuk pertumbuhan dan perkembangbiakan nyamuk. Suhu dan kelembaban udara di Desa Lifuleo Kabupaten Kupang mendukung untuk pertumbuhan nyamuk Anopheles spp.

Pengamatan habitat yang dilakukan pada pagi hari selama penangkapan berlangsung di Desa Lifuleo, Kecamatan Kupang Barat, menemukan larva Anopheles yang di kolam ikan dan rawa-rawa. Di Desa Lifuleo An. barbirostris dan An. subpictus ditemukan pada dua jenis habitat, yaitu rawa-rawa dan kolam ikan (mujair dan bandeng). Hal ini sama dengan di Sulawesi Tengah. Larva nyamuk malaria An. barbirostris terdapat pada dataran rendah, perbukitan dan pegunungan (sawah, kobakan air tawar, mata air, kolam ikan tawar, saluran/selokan dan rawa-rawa), An. subpictus di empang (kolam ikan) dan rawa-rawa (Jastal et al. 2005). Berbeda dengan di daerah pantai Banyuwangi, larva $A n$. barbirostris ditemukan di habitat lagun, kobakan, dan mata air. An. vagus terdapat di lagun dan kobakan, sedangkan An. subpictus ditemukan hanya di mata air (Shinta et al. 2003)

Habitat nyamuk Anopheles spp. di Desa Lifuleo adalah genangan air yang bersifat permanen (kolam ikan), yang selalu ada air sepanjang tahun. Hal ini menyebabkan nyamuk menggunakan tempat tersebut sebagai habitat. An. barbirostris dan An. subpictus selaku vektor malaria di NTT, juga ada sepanjang tahun sehingga dapat berakibat kasus malaria akan ada setiap tahun di Desa Lifuleo.

Mengingat habitat nyamuk A. barbirostris dan A. subpictus selaku vektor malaria di daerah ini merupakan genangan air yang permanen maka pengendalian stadium pradewasa (larva) merupakan cara yang tepat dalam menurunkan kepadatan populasi vektor. Metode pengendalian dapat berupa pembersihan habitat 62 perkembangbiakan nyamuk dari lumut yang merupakan makanan bagi jenis larva Anopheles spp. yang hidup di air payau.

Di samping itu, penggunaan kelambu merupakan salah satu cara penduduk untuk melindungi diri terhadap gigitan nyamuk vektor. Hal ini cara yang tepat mengingat puncak menghisap darah nyamuk vektor terjadi pada sekitar tengah malam sampai dini hari, di saat sebagian besar masyarakat istirahat (tidur). Masyarakat juga dihimbau mengurangi aktivitas di luar rumah pada malam hari. Jika tetap beraktivitas maka dianjurkan untuk menggunakan repelen (penolak nyamuk).

\section{KESIMPULAN}

Enam spesies Anopheles yang berhasil ditemukan di Desa Lifuleo Kecamatan Kupang Barat, yaitu An. barbirostris, An. subpictus, An. annularis, An. vagus, An. umbrosus, dan An. indefinitus. Spesies dengan frekuensi tertinggi adalah An. barbirostris (68,31\%), An. subpictus (19,18\%), An. vagus (7,36\%), dan An. umbrosus (3,63\%). Puncak menghisap darah berlangsung pada sekitar tengah malam. An. barbirostris mempunyai puncak menghisap darah di dalam rumah pada pukul 22:00-04:00 dan di luar rumah pada pukul 21:00-04:00, An. subpictus di dalam rumah 20:00-01:00 dan di luar rumah 22:00-23:00, An. vagus di dalam dan di luar rumah 22:00-23:00, An. umbrosus di luar rumah pukul 20:00-03:00, di dalam rumah 22:00-23:00. Berdasarkan rata-rata kepadatan setiap jam, nyamuk Anopheles spp. di Desa Lifuleo bersifat eksofagik dan eksofilik, yaitu lebih senang menggigit di luar rumah daripada di dalam rumah dan lebih senang beristirahat di luar rumah.

\section{UCAPAN TERIMA KASIH}

Terima kasih penulis sampaikan kepada Ketua Jurusan Kesehatan Lingkungan Politeknik Kesehatan Dinas Kesehatan Kupang, Ibu R. H. Kristina, SKM, M.Kes atas bantuan moril selama penelitian berlangsung. Disamping itu, penghargaan penulis sampaikan kepada Kepala 
Dusun Tuadale Desa Lifuleo yang telah membantu menyediakan tempat selama penelitian di Desa Lifuleo, Hanani (Lokalitbangkes Waikabubak, NTT), dan adik-adik Mahasiswa Jurusan Kesehatan Lingkungan Kupang (Tim Kolektor) yang telah membantu secara teknis selama penelitian. Ungkapan terima kasih juga disampaikan kepada Bapak Prof. Dr. drh. Singgih H. Sigit, MS, Bapak Dr. drh. FX. Koesharto, MS, dan seluruh dosendosen dan tenaga kependidikan di Program Studi Parasitologi dan Entomologi Kesehatan Sekolah Pascasarjana IPB Bogor. Penelitian ini didanai oleh Pusren-Gun SDM Kes Depkes RI.

\section{DAFTAR PUSTAKA}

[BMGKK] Badan Meteorologi dan Geofisika Kabupaten Kupang. 2009. Data Klimatologi. Kupang: BMGKK.

Barodji, Sumardi, Suwaryono T, Rahardjo. 2000. Beberapa aspek bionomik vektor Anopheles subpictus Grassi di Kecamatan Tanjung Bunga, Flores Timur, NTT. Buletin Penelitian Kesehatan 27:268-281.

Depkes RI. 2001. Epidemiologi Malaria. Jakarta: Ditjen PPM dan PL.

Depkes RI. 2007. Vektor Malaria di Indonesia. Jakarta: Ditjen PPM dan PL.

Dinkes Provinsi NTT 2009. Laporan Kasus Penyakit di Propinsi Nusa Tenggara Timur. Kupang: Dinas Kesehatan.

Dinkes Kabupaten Kupang. 2009. Laporan Kasus Malaria di Kabupaten Kupang Provinsi Nusa Tenggara Timur. Kupang: Dinkes Kabupaten Kupang.

Effendi A. 2002. Studi Komunitas Nyamuk Anopheles di Daerah Kokap Kabupaten Kulon Progo, Daerah Istimewa Yogyakarta. Master Thesis. Bogor: Institut Pertanian Bogor.

Elyazar IR, Gething PW, Patil AP, Rogayah H, Sariwati E, Palupi NW, Tarmizi SN, Kusriastuti R, Baird JK, Hay SI. 2012. Plasmodium vivax malaria endemicity in Indonesia in 2010. PLoS One 7:e37325.

Elyazar IR, Gething PW, PatilAP, Rogayah H, Sariwati E, Palupi NW, Tarmizi SN, Kusriastuti R, Baird JK, Hay SI. 2011. Plasmodium falciparum malaria endemicity in Indonesia in 2010. PLoS One 6:e21315.
Garjito TA, Jastal, Wijaya Y, Lili. 2004. Studi bioekologi nyamuk Anopheles di wilayah Pantai Timur Kabupaten Parigi-Muotong, Sulawesi Tengah. Buletin Penelitian Kesehatan 32:49-61. Hadi, UK. 2010. Entomologi Kesehatan di Indonesia: Masalah, Kendala dan Tantangannya. Di dalam: Hari Sutrisno et al. (Eds.), Prosiding Seminar Nasional V Perhimpunan Entomoogi Indonesia. Pemberdayaan Keanekaragaman Serangga untuk Peningkatan Kesejahteraan Masyarakat (Bogor, 18-29 Maret 2008). pp 10-32. Bogor: Perhimpunan Entomologi Indonesia.

Hakim L, Ipa M. 2007. Sistem kewaspadaan dini KLB malaria berdasarkan curah hujan, kepadatan vektor dan kesakitan malaria di Kabupaten Sukabumi. Media Litbang Kesehatan 7:34-40.

Jastal. 2005. Perilaku Nyamuk Anopheles Menghisap Darah di Desa Tongoa, Donggala, Sulawesi Tengah. Master Thesis. Bogor: Institut Pertanian Bogor.

Limrat D, Rojruthai B, Apriwathnason C, Samung Y. 2001. Anopheles barbirostris/campestris as a probable vector of malaria in Aranyaprahet, $\mathrm{Sa}$ Kaeo Province, The Southeast Asian Journal of Tropical Medicine and Public Health 32:739744.

Munif A, Sudomo M, Soekarno. 2008. Bionomi Anopheles spp. di daerah endemis malaria di Kecamatan Lengkong, Kabupaten F. Buletin Penelitian Kesehatan 35:57-88.

O'Connor CT, Soepanto A. 1999. Kunci Bergambar Nyamuk Anopheles Dewasa di Indonesia. Jakarta: Dit.Jen. PPM \&PLP.

Puskesmas Batakte. 2009. Laporan Kasus Penyakit di Kecamatan Kupang Barat. Kupang: Puskesmas Batakte.

Russel PF, West LS, Manwell RD, Macdonal G. 1963. Practical Malariology. $2^{\text {nd }}$ Edition. London: Oxrford University Press.

Shinta, Sukowati S, Mardiana. 2003. Komposisi spesies dominasi nyamuk Anopheles di daerah Pantai Banyuwangi, Jawa Timur. Media Litbang Kesehatan 8:1-8.

Sigit SH. 2006. Arti penting informasi bioekologi vektor dan hama permukiman dalam epidemiologi dan pengendalian penyakit bersumber binatang. Di dalam: Jastal et al. (Eds.), Seminar "Peranan Penelitian dan Pengembangan Kesehatan dalam Mendukung Program Pemberantasan Penyakit Bersumber Binatang di Sulawesi Tengah (Palu, 26-27 Juli 2006). pp: 6-12. Palu: Lokalitbang 
Pemberantasan Penyakit Bersumber Binatang di Sulawesi Tengah.

WHO. 2005. Vector Control for Malaria and Other Mosquito Borne Diseases. WHO Technical Report. Series 857.
WHO 2012. World malaria report. Fact Sheet. Available at: http://www.who.int/malaria/ publications/world_malaria_report_2012/ wmr2012_factsheet.pdf. [accessed 17 desember 2012]. 